\title{
The relationship between $A B O$ blood types and development of cerebral venous sinus thrombosis
}

\section{ABO kan grupları ille serebral venöz sinüs trombozu gelişimi arasındaki ilişki}

\author{
Aslı Bolayır, Burhanettin Çiğdem
}

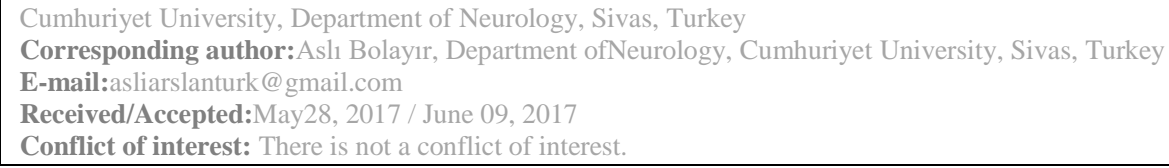

\section{SUMMARY}

Objective: Several studies in the last few decades demonstrated that patients with non-O blood groups (A, B, AB) have increased prothrombic tendency. In addition, many thrombotic disorders have been shown to be closely related to the blood group. However, the role of blood types in cerebral venous sinus thrombosis (CVST) development is unknown.

Method: Our study included 41 patients who visited the Neurology Department at Cumhuriyet University Hospital and who were diagnosed with CVST between the dates 01/01/2008 and 30/09/2016, together with 50 age- and sex-matched controls. The patient and control groups were compared in terms of blood group distribution. In addition, the patient group was divided into two groups according to whether they had parenchymal brain lesions or not, and the effect of the blood group on the prognosis was also assessed.

Results: While the blood group distribution in the control group reflected the overall distribution of the Turkish population, the proportion of the non-O blood group in the patient group was higher than in the control group, however the difference between the two groups was not statistically significant. Similarly, there was no statistically significant difference in blood group distribution between patients with and without parenchymal lesions in the patient group. Logistic regression analysis showed that the blood group was not an independent variable in the development of CVST. Conclusions: As a result, the percentage of non-O blood group was higher in patients with CVST than healthy controls; however this is not statistically significant. There is a need for more prospective and extensive future studies on this issue. Key words: Cerebral venous sinus thrombosis, ABO blood group, Prothrombic tendency

\section{ÖZET}

Amaç: Geçtiğimiz birkaç dekat boyunca çok sayıda çalışma ile O dişı (A, B, AB) kan grubuna sahip hastalarda artmış protrombotik eğilim olduğu ortaya konmuştur.Ek olarak birçok trombotik hastalıkla kan grubu arasında yakın ilişki gösterilmiştir. Ancak kan gruplarının serebral venöz sinüs trombozu(SVST) gelişimindeki yeri bilinmemektedir. Yöntem: Çalışmamıza retrospektif olarak 01/01/2008- 30/09/2016 tarihleri arasında Cumhuriyet Üniversitesi Hastanesi Nöroloji Ana Bilim Dalı'na başvuran ve SVST tanısı kesinleşmiş 41 hasta ile benzer yaş ve cinsiyete sahip 50 kontrol dahil edildi.Hasta grubu ve kontrol grubu kan grubu dağılımı açısından kıyaslandı. Bunun yanında hasta grubu kendi içinde beyin parankimal lezyonu olan ve olmayanlar olarak ikiye ayrılarak kan grubunun prognoz üzerindeki etkisi de değerlendirildi.

Bulgular: Kontrol grubundaki kan grubu dağılımı Türk toplumunun genel dağılımını yansıtırken, hasta grubunda O dışı kan grubu oranı kontrol grubundan daha yüksekti (\%34,\%19,5), ancak her iki grup arasındaki bu fark istatistiksel olarak anlamlı değildi. Benzer şekilde hasta grubundaki parankimal lezyonu olan ve olmayan hastalar arasında da kan grubu dağılımı açısından istatistiksel açıdan anlamlı fark yoktu.Yapılan lojistik regresyon analizinde de kan grubu SVST gelişiminde bağımsız bir değişken olarak saptanmadı.

Sonuç: Sonuç olarak, O dışı kan grubu yüzdesi SVST'li hastalarda sağlıklı kontrollerden daha yüksektir, ancak bu durum istatistiksel olarak anlamlı değildir. İleride bu konu ile ilgili daha fazla prospektif ve geniş hasta grubuna sahip çalışmaya ihtiyaç vardır.

Anahtar sözcükler: Serebral venöz sinus trombozu, ABO kan grubu, Protrombotik eğilim 


\section{INTRODUCTION}

Cerebral venous sinus thrombosis (CVST) is a neurological condition that is rarer than the arterial occlusive diseases of the brain, but highly serious ${ }^{1}$.CVST constitutes approximately $1 \%$ of all strokes. While it may affect all age groups, it is seen more frequently in young adults. Clinical signs are highly variable and dependent on the severity of clinical results, the magnitude of the thrombotic process, its localization and severity ${ }^{1 \text {, }}$ 2. The most frequently encountered clinical symptoms and signs are headache indicating increased intracranial pressure, nausea, vomiting and papilla edema, focal or generalized epileptic seizures that indicate participation of the brain parenchyma in the disease process, and focal neurological deficits. Problematic prognostic factors are old age and complications such as involvement of cortical and deep cerebral venous systems, increased intracranial pressure, loss of consciousness and accompanied parenchymal lesion, as well as pulmonary embolism ${ }^{1,3}$.

There are various reasons in the etiology of CVST. In practice, in addition to reasons that lead to peripheral vein thrombosis, local reasons in the cranial region (trauma, infection in the anatomic structures neighboring the sinuses and tumoral reasons) should also be considered ${ }^{2}$. Post-partum period and usage of oral contraceptives are the most frequently reasons in young women in their reproductive periods ${ }^{2}$.

Suitability of ABO blood group is primarily important for safe blood transfusion and tissue transplantation. However, ABO antigens are not limited to the membranes of red blood cells. Various plasma proteins including the von Willebrand factor (VWF), factor VIII(F VIII) and $\alpha 2$-macroglobulin are also expressed ${ }^{4}$. Several studies in the last few decades demonstrated that there are increased levels of FVIII and VWF in patients with non-O blood groups $(\mathrm{A}, \mathrm{B}, \mathrm{AB})$, and therefore, individuals with these blood groups have increased prothrombic tendency ${ }^{5-7}$. Many studies have shown relationships in patients with non-O blood groups with increased acute myocardial infarction, coronary artery disease, deep venous thrombosis (DVT) in the lower extremity, and ischemic stroke development ${ }^{5-15}$. However, the role of blood groups in CVST development is unknown. Therefore, in our study, we investigated the role of blood groups in CVST and their effects on the severity of the disease by analyzing the blood groups of acute period CVST patients retrospectively and comparing them to the controls with similar ages and genders.

\section{MATERIAL AND METHODS}

\section{Sample:}

This study included 41 patients who visited the Department of Neurology at Cumhuriyet University Hospital between the dates 01/01/2008 and 30/09/2016 who were diagnosed with CVST. The diagnosis of CVST was based on the patient's history, neurological examination findings, and demonstration of the occlusion in the venous sinus via cranial magnetic resonance imaging (cMRI), MRI venography or digital substraction angiography (DSA). No quotas were set among the patients in terms of sex. Exclusion criteria were being under the age of 18 , history of ischemic stroke, peripheral vascular disease, pulmonary embolism, infection, acute myocardial infarction, and usage of antiaggregant, anticoagulant or lipid lowering drugs. In the patient group, in addition to routine hematologic and biochemical tests including glucose, blood urea nitrogen (BUN), creatinine, liver function tests, electrolytes and thyroid function tests, antinuclear antibody, antidouble-stranded DNA, lupus anticoagulant, antiphospholipid antibodies, protein $\mathrm{C}$ and $\mathrm{S}$, antithrombin III and factor V Leiden mutation were also investigated. The control group consisted of 50 volunteers who did not have any systemic disease under monitoring that provided blood samples for any reason other than CVST, and were of the age group in similarity to our group of patients.

\section{Analysis of the Blood Samples:}

The blood samples of all patients included in the study were collected in the first 24 hours of hospitalization from the antecubital vein. The analysis of blood groups was carried out in compliance with the instructions of the manufacturer using a Wizard purification kit (Promega Inc., Madison,Wisconsin,USA). For complete blood count, the Diagon kit was used in the Mindray BC-6800 device. The glucose, creatinine and BUN measurements were analyzed in a fully automated way with the nephelometric method using a Beckman Coulter AU5800 device.

\section{Statistical Analysis:}

For the statistical analysis of the data obtained in our study, the SPSS (Ver: 22.0) software was used. The data were analyzed using descriptive analysis 
(mean and standard deviation). Additionally, in the analyses of the data, analysis of variance was used when parametric test assumptions were complied with (Kolmogorov-Smirnov), and Bonferroni, Mann-Whitney U and Chi-Squared tests were used when they were not. Categorical data were presented as numbers and percentages. In order to determine the independent variables in development of CVST, logistic regression analysis was used. A value of $p<0.05$ was accepted as statistically significant.

\section{RESULTS}

There was no statistically significant difference between the patient and control groups in terms of age or sex $(\mathrm{p}=0.08, \mathrm{p}=0.92)$; however glucose and platelet count were higher in the patient group $(\mathrm{p}=0.01, \mathrm{p}<0.001)($ Table 1$)$. While 40 patients were diagnosed using MRI and MRI venography, one patient was diagnosed using DSA. As the most frequently symptom in the patient group was headache $(73.2 \%)$, the most frequent sign was presence of papilledema (85.4\%) (Table 2 ). The most frequently involved sinuses were the sagittal sinus and the transverse sinus (Table 3). Among the etiologic reasons, the most frequently encountered was postpartum state (19.5\%), while no etiologic reasons were found in 18 patients (Table 4).

Table 1. Thebaselinedemographic, clinical, andlaboratorycharacteristics of thecontrolandthepatientgroups.

Abbreviations: CVST: cerebralvenoussinusthrombosis; DM: diabetesmellitus; Hb: hemoglobin; HT: hypertension;SD: standarddeviation; WBC: whitebloodcell.

\begin{tabular}{|c|c|c|c|c|}
\hline & $\begin{array}{c}\text { Control Group } \\
(\mathbf{n}=50)\end{array}$ & $\begin{array}{c}\text { CVSTGroup } \\
(n=41)\end{array}$ & $\mathrm{X}^{2}$ value & pvalues \\
\hline Male, n(\%) & $21(38.9 \%)$ & $16(39.0 \%)$ & 0.01 & 0.92 \\
\hline HT Presence, n(\%) & $15(30 \%)$ & $12(29.3 \%)$ & 1.76 & 0.92 \\
\hline $\begin{array}{l}\text { DM } \\
\text { n(\%) }\end{array}$ & $10(20 \%)$ & $8(19.5 \%)$ & 2.21 & 0.93 \\
\hline Smoking, n(\%) & $25(50 \%)$ & $21(51.2 \%)$ & 3.35 & 0.61 \\
\hline $\begin{array}{l}\text { Age (mean } \pm \text { SD) } \\
(\text { min-max })\end{array}$ & $\begin{array}{c}45.80 \pm 12.52 \\
(23-73) \\
\end{array}$ & $\begin{array}{c}41.67 \pm 12.67 \\
(24-77) \\
\end{array}$ & & 0.08 \\
\hline $\begin{array}{l}\text { BUN(mg/dL)(mean } \\
\pm \text { SD) } \\
(\text { min-max })\end{array}$ & $\begin{array}{c}14.26 \pm 5.01 \\
(6.5-33)\end{array}$ & $\begin{array}{c}13.88 \pm 5.28 \\
(5.7-32)\end{array}$ & & 0.09 \\
\hline $\begin{array}{l}\text { Creatine }(\mathrm{mgr} / \mathrm{dL}) \\
(\text { mean } \pm \mathrm{SD}) \\
(\min -\mathbf{m a x})\end{array}$ & $\begin{array}{l}0.80 \pm 0.12 \\
(0.56-1.2)\end{array}$ & $\begin{array}{l}0.79 \pm 0.12 \\
(0.56-1.2)\end{array}$ & & 0.06 \\
\hline $\begin{array}{l}\text { Glucose }(\mathrm{mg} / \mathrm{dL}) \\
(\operatorname{mean} \pm \mathrm{SD}) \\
(\min -\mathrm{max})\end{array}$ & $\begin{array}{c}98.94 \pm 24.32 \\
(68-195)\end{array}$ & $\begin{array}{c}113.59 \pm 37.95 \\
(73-267)\end{array}$ & & 0.01 \\
\hline $\begin{array}{l}\mathrm{Hb}(\mathrm{g} / \mathrm{dL})(\text { mean } \pm \\
\mathrm{SD}) \\
(\mathrm{min}-\mathrm{max})\end{array}$ & $\begin{array}{c}14.32 \pm 1.28 \\
(10.2-17.7)\end{array}$ & $\begin{array}{c}14.22 \pm 1.89 \\
(9.8-19)\end{array}$ & & 0.59 \\
\hline $\begin{array}{l}\text { WBC } \times \\
/ \mu \mathrm{l}(\operatorname{mean} \pm \mathrm{SD}) \\
(\min -\mathbf{m a x})\end{array}$ & $\begin{array}{c}6937.26 \pm 1935.20 \\
(600-12200)\end{array}$ & $\begin{array}{c}7370.82 \pm 1708.10 \\
(700-14000)\end{array}$ & & 0.55 \\
\hline $\begin{array}{l}\text { Platelet } \\
\times 10^{3} / \mathrm{L}(\text { mean } \pm \text { SD }) \\
(\text { min-max })\end{array}$ & $\begin{array}{c}222.80 \pm 49.39 \\
(140-323)\end{array}$ & $\begin{array}{c}290.60 \pm 63.63 \\
(164-652)\end{array}$ & & $<0.001$ \\
\hline
\end{tabular}

Table 2. Clinicalfeatures of patientgroup.

\begin{tabular}{|l|c|c|}
\hline ClinicalFeatures & Number of Patients(n) & Percentage \\
\hline Headache & 30 & $73.2 \%$ \\
\hline Hemiparesis/hemihypoesthesia & 18 & $43.9 \%$ \\
\hline Epilepticseizure & 19 & $46.3 \%$ \\
\hline Papilloedema & 35 & $85.4 \%$ \\
\hline Consciousnessloss & 9 & $22.0 \%$ \\
\hline
\end{tabular}


Table 3. Involvedsinuses in patientgroup.

\begin{tabular}{|l|c|c|}
\hline InvolvedSinuses & Number of Patients(n) & Percentage \\
\hline SuperiorSagittalSinus & 23 & $56.1 \%$ \\
\hline TransverseSinus & 30 & $73.2 \%$ \\
\hline Sigmoid Sinus & 19 & $46.3 \%$ \\
\hline CorticalVein & 8 & $19.5 \%$ \\
\hline CavernousSinus & 0 & $0 \%$ \\
\hline JugularVein & 2 & $4.8 \%$ \\
\hline
\end{tabular}

Table 4. Etiologicfactorsin patientgroup.

\begin{tabular}{|l|c|c|}
\hline Etiologicfactors & Number of Patients(n) & Percentage \\
\hline Pregnancy & 1 & $2.4 \%$ \\
\hline SpinalAnesthesia & 6 & $14.6 \%$ \\
\hline Pregnancy+ SpinalAnesthesia & 1 & $2.4 \%$ \\
\hline Postpartum & 8 & $19.5 \%$ \\
\hline Behçet Disease & 1 & $2.4 \%$ \\
\hline Oral ContraceptiveDrugUse & 4 & $9.8 \%$ \\
\hline Hypercoagulopathy & 2 & $4.8 \%$ \\
\hline Unidentified & 18 & $43.9 \%$ \\
\hline
\end{tabular}

According to the results of the logisticregressionanalysis, high platelet counts was found as an independent risk factor for CVST

development, while blood groups were not determined as independent risk factors(Table 5).

Table 5. Logisticregressionanalysis of independentsignificantvariables in CVST.

Abbreviations:CI: confidenceinterval; SE: standarderror; ß:regression coefficient.

\begin{tabular}{|l|c|c|c|c|c|}
\hline & B & S.E. & Sig. & $\operatorname{Exp(B)}$ & $\begin{array}{c}\text { 95\% C.I.for } \\
\text { EXP(B) }\end{array}$ \\
\hline PlateletCount & 0.02 & 0.01 & 0.01 & 1.02 & $1.01-1.03$ \\
\hline Blood Group & -0.44 & 0.29 & 0.14 & 0.65 & $0.36-1.16$ \\
\hline Constant & -34.91 & 13.21 & 0.08 & 0.00 & \\
\hline
\end{tabular}

Considering the blood groups of the patient and control groups (Table 6); 22 in the control group had the blood group A (44\%), 3 had AB (6\%), 17 had $\mathrm{O}(34 \%)$ and 8 had $\mathrm{B}(16 \%)$, and these results were similar to those in the blood group distribution study conducted in Turkey by Akin and Dostbil (16). In the patient group, 19 patients had the blood group $\mathrm{A}(46.3 \%), 8$ had $\mathrm{AB}(19.5 \%), 8$ had $\mathrm{O}(19.5 \%)$, and 6 had $\mathrm{B}(14.6 \%)$. While there was a noticeable difference in the percentages of patients with the blood group $\mathrm{O}$ in the two groups, there was no significant difference found between the groups in terms of blood group distribution $\left(\mathrm{X}^{2}=5.17, \mathrm{p}=0.16\right)$.

Table 6. Blood groupdistribution in patientandcontrolgroups.

\begin{tabular}{|l|c|c|}
\hline Blood Group & Control Group,n(\%) & CVST Group,n(\%) \\
\hline A Group & $22(44.0 \%)$ & $19(46.3 \%)$ \\
\hline AB Group & $3(6.0 \%)$ & $8(19.5 \%)$ \\
\hline O Group & $17(34.0 \%)$ & $8(19.5 \%)$ \\
\hline B Group & $8(16.0 \%)$ & $6(14.6 \%)$ \\
\hline
\end{tabular}

The patient group was then divided into two subgroups based on whether there is a presence of parenchymal brain lesion or not. While there were parenchymal brain lesions on 19 patients (46.3\%), there were not in 22 patients. In the comparison of the non- $\mathrm{O}$ and $\mathrm{O}$ blood groups in all 3 groups(Table 7 ), while 33 of the individuals in the control group
(66\%) had a non-O blood group, the blood group of the individuals in the patient group was non-O for 16 patients $(84.2 \%)$ with no lesions and 17 patients $(77.3 \%)$ with lesions; however, these differences among the three groups were not statistically significant $\left(\mathrm{X}^{2}=2.61, \mathrm{p}=0.27\right)$. 
Table 7. Thedistribution of thenon-O and $\mathrm{O}$ groups in patientandcontrolgroups.

Abbreviations: L(+):patientswithparenchymallesion; L(-):patientswithoutparenchymallesion.

\begin{tabular}{|l|c|c|c|}
\hline Blood Group & $\begin{array}{c}\text { Control } \\
\text { Group,n(\%) }\end{array}$ & \multicolumn{2}{|c|}{ CVST Group,n(\%) } \\
\hline Non-OGroup & $33(66 \%)$ & $\mathrm{L}(+)$ & $\mathrm{L}(-)$ \\
\cline { 2 - 4 } & $17(34 \%)$ & $16(84.2 \%)$ & $17(77.3 \%)$ \\
\hline O Group & $3(18.5 \%)$ & $5(22.7 \%)$ \\
\hline
\end{tabular}

\section{DISCUSSION}

With this study, we determined that the ratio of patients with the blood group non-O among CVST patients is higher than that among healthy adults in the same age group; however, this difference was not statistically significant. Additionally, while the high platelet count was an independent risk factor for CVST, it was not possible to say this for distribution of blood groups.

It is known that the development process of venous thrombosis is different to that of arterial thrombosis, but this process has not yet been understood completely ${ }^{17}$. It has been accepted for years that there should be changes in blood composition, blood circulation or blood vessel walls in order for venous thrombosis to develop (Virchow triad) ${ }^{17}$. Among these 3, the most frequently investigated is blood composition. It is currently not entirely known how stasis in blood flow or changes in blood vessel walls lead to thrombosis ${ }^{17}$. In difference to arterial thrombosis, there is no need for blood vessel wall damage for development of venous thrombosis; however, it is not entirely known what the situation that starts the connection to the normal non-thrombogenic endothelium. There are two clues about the situation that starts thrombosis: inflammation and stasis. Local inflammation is characterized by the activation of endothelium. Activation of endothelium rapidly leads to secretion of the von Willebrand factor (VWF) and Weibel Palade bodies connected to the membrane that contain Pselectin. These two proteins attack the endothelium surface, and thus, thrombosis starts with the aggression of erythrocytes, fibrins and platelets ${ }^{17}$. This newly secreted VWF is both larger and more adhesive than the VWF present in the serum ${ }^{18}$. Therefore, it can bind not only platelets, but also leukocytes ${ }^{18,19}$. Stasis leads to a rapid desaturation in the hemoglobin in erythrocytes in the place it takes place, and this stimulates hypoxic response in leukocytes, platelets and endothelial cells. Hypoxia induces thrombosis in various ways. One of these is the activation of the endothelium and exocytosis of Weibel Palade bodies ${ }^{17}$.
The relationship between VWF and venous thrombosis is well-known. It is known that VWF levels are higher in individuals with a non-O blood group than those with an $\mathrm{O}$ blood group ${ }^{8,9,17}$. Therefore, non-O blood groups are accepted as a risk factor for development of $\mathrm{DVT}^{11,12,20}$. Increased VWF levels are correlated with increased FVIII levels. FVIII must be in relation with VFW to protect itself from rapid degradation and stay in the circulation ${ }^{17}$. Until now, high FVIII levels have been related to non-O blood groups, high VWF and high DVT risk, because the effects of VWF on coagulation could not be demonstrated in the in vitro tests carried out 12,17,18. However, independently of its role as a FVIII carrier in thrombosis development, VWF is significant in terms of being an intermediary of blood cells sticking to the blood vessel walls as a result of endothelium activation in the initial phases of thrombosis development ${ }^{17}$.In our study, the ratio of the patients with the blood group non-O was noticeably higher in comparison to the control group; however, no statistically significant difference was found between the two group in terms of blood group distribution. After the patient group was divided into two groups in terms of whether they have a brain lesion or not, in the comparison of the 3 groups, the percentages of the blood group non-O in the patients both with and without lesions were higher than those in the control group, but the difference was not statistically significant. The fact that the percentage of non-O blood groups in the patient group was found higher than that of the control group, though not statistically significant, may be explained by the increased tendency of thrombosis in patients with non-O blood groups as in studies previously conducted with patients diagnosed with $\mathrm{DVT}^{11,12,20}$. The reason for the statistical insignificance of this difference in percentages may be related to the small number of our patient group. The finding that there was no noticeable difference between the percentages of the patients with and without brain parenchymal lesions, shows that blood groups do not have an effect on the severity of CVST. Similarly, according to our results, it 
may be argued that blood groups do not have an independent effect on CVST development either.

The main limitations of our study are that other markers that play a role in thrombosis development were not considered, and the number of patients was small because it was a single-centered study. Additionally, our study did not have information about the short- and long-term prognosis of the patients.

In conclusion, the ratio of the patients of CVST with the blood group non-O was higher than that in the healthy controls; however, this difference was not found statistically significant. There is a need for more prospective and extensive future studies on this issue.

\section{REFERENCES}

1. Masuhr F, Mehraein S, Einhaupl K. Cerebral venous and sinüs thrombosis. J Neurol 2004; 251: 11-23.

2. Ehtisham A, Stern BJ. Cerebral venous thrombosis: a review. Neurologist 2006; 12: 32-8.

3. Zubkov AY, McBane RD, Brown RD, Rabinstein AA. Brain lesions in cerebral venous sinüs thrombosis. Stroke 2009; 40(4): 1509-1511.

4. Matsui T, Fujimura Y, Nishida S, Titani K. Human plasma alpha 2-macroglobulin and vonWillebrand factor possess covalently linked $\mathrm{ABO}(\mathrm{H})$ blood group antigens in subjects with corresponding ABO phenotype. Blood 1993; 69: 1691-5.

5. Whincup PH, Cook DG, Phillips AN, Shaper AG. ABO blood group and ischemic heart disease in British men. BMJ 1990; 300: 167982.

6. Cronenwett JL, DavisJr JT, Garrett HE. ABO groupsand serum lipids in female atherosclerosis. J CardiovascSurg 1983; 24 : 658-61.

7. Garrison RJ, Havlisk RJ, Harris RB, Feinleib M, Kannel WB, Padgett SJ. ABO blood group and cardiovascular disease: the Framingham study. Atherosclerosis 1976; 25: 311-8.

8. Platt D, Muhlberg W, Kiehl L, Schmitt-Ruth R. $\mathrm{ABO}$ blood group system, age, sex, risk factors and cardiac infarction. Arch Gerontol Geriatr1985; 4: 241-9.

9. Meade TW, Cooper JA, Stirling Y, Howarth DJ, Ruddock V, Miller GJ. Factor VIII, ABO blood group and the incidence of ischaemic heart disease. Br J Haematol1994; 88: 601-7.

10. Thompson SG, Kienast J, Pyke SDM, Haverkate F, van de Loo JCW. Hemostatic factors and the risk of myocardial infarction or sudden death in patients with angina pectoris. N Engl J Med 1995; 332: 635-41.

11. Allan TM. ABO blood groups and age groups in surgical venous thromboembolism. Atherosclerosis 1976; 23: 141-2.

12. Jick H, Porter J. Thrombophlebitis of the lower extremities and $\mathrm{ABO}$ blood type. Arch Intern Med 1978; 138: 1566-7.

13. Gonzalez Ordonez AJ, Medina Rodriguez JM, Martin L, Alvarez V, Coto E. The O blood group protects against venous thromboembolismin individuals with the factor $\mathrm{V}$ Leiden but not the prothrombin (factor II G20210A) mutation. Blood Coagul Fibrinolysis 1999; 10: 303-7.

14. Yang N, Zhang B, Xie L, et al. The association baseline NIH Stroke Scales core with ABO bloodsubtypes in young patients withacute ischemicstroke. Atherosclerosis 2014; 236: 144-9.

15. Sabino AP, Ribeiro DD, Domingheti CP. ABO blood group polymorphisms and risk for ischemic stroke and peripheral arterial disease. Mol Biol Rep 2014; 41: 1771-7.

16. Akın G, Dostbil N. Türkiye'de Kan Grubu Araştırmaları. Ankara Üniversitesi Dil ve Tarih-Coğrafya Fakültesi Dergisi 2005; 45:115.

17. Lo'pez JA, Chen J. Pathophysiology of venous thrombosis. Thromb Res 2009; 123 (suppl 4): 30-4.

18. Bernardo A, Ball C, Nolasco L, Choi H, Moake JL, Dong JF. Platelet s adhered to endothelial cell-bound ultra-large vonWillebrand factor strings support leukocyte tethering and Rolling under high shear stress. J Thromb Haemost 2005; 3: 562-70.

19. Wick TM, Moake JL, Udden MM, Eskin SG, Sears DA, McIntire LV. Unusually large vonWillebrand factor multimers increase adhesion of sickle erythrocytes to human endothelial cells under controlled flow. J Clin Invest 1987; 80: 905-10.

20. WuO,Bayoumı N, VickersMa, Clark P. $\mathrm{ABO}(\mathrm{H})$ blood groups and vascular disease: a systematic review and meta-analysis. $\mathbf{J}$ Thromb Haemost 2008; 6: 62-9. 